Artigo Original

\title{
Minimum trends in air temperature in the municipality of Porto Velho - RO from 1971 to 2016
}

\author{
Tendências mínimas da temperatura do ar no município de Porto Velho - RO no período de 1971 a 2016
Camila Bermond Ruezzene', Renata Gonçalves Aguiar", Graciela Redies Fischer 'I", Nara Luísa Reis de Andrade ${ }^{\mathrm{Iv}}$, Renato Billia de Mirandav, Frederico Fabio Mauad ${ }^{\mathrm{vI}}$

\section{Abstract}

In recent years, studies focused on the climate of the Amazon have been the focus of major research mainly to identify possible temperature trends. The objective of this study was to analyze the trends and the years of abrupt changes in temperature that occurred in the Southwest Amazon from 1971 to 2016 in the municipality of Porto Velho-RO. The study area is located in the municipality of Porto Velho at the Meteorological Station of Surface, we used average daily temperature data and subdivided into climatological series from 1971 to 2006 and 1981 to 2016. The Mann-Kendall and Pettitt tests were used to verify trends. A positive trend was observed for the Mann-Kendall test for the months of January, February, March, April, June, September, October and December of 1971 to 2006 and for the years 1981 to 2016 only the months of March and June presented a trend temperature increase. The Pettitt test indicated a sudden change in the data series coinciding with most of the months that showed a tendency to increase the minimum air temperature by the Mann-Kendall test in the years 1971 to 2006. From 1981 to 2016 the Pettitt test indicated the months of March and June with changes in the minimum air temperature, this result also coincided with the months with positive trends.

Keywords: climate of the Amazon; Mann-Kendall test; Pettitt's test; Increase in minimum temperature

\section{Resumo}

Nos últimos anos, estudos voltados para o clima da Amazônia tem sido foco de grandes pesquisas principalmente para identificação de possíveis tendências de temperatura. Desta forma objetivo desde estudo foi analisar as tendências e os anos de alterações bruscas de temperatura que ocorreram no Sudoeste Amazônia nos anos de 1971 a 2016 no município de Porto Velho-RO. A área de estudo está localizada no município de Porto Velho na Estação Meteorológica de Superfície, foram utilizados dados médios diário de temperatura e subdivididos em séries climatológicas de 1971 a 2006 e 1981 a 2016. Os testes de Mann-Kendall e Pettitt foram empregados para verificação das tendências. Foi constatado tendência positiva pelo teste de Mann-Kendall para os meses de janeiro, fevereiro, março, abril, junho, setembro, outubro e dezembro de 1971 a 2006 e para os anos de 1981 a 2016 apenas os meses de março e junho apresentaram tendência de aumento da temperatura mínima. O teste de Pettitt indicou uma mudança brusca na série de dados coincidindo com a maioria dos meses que apresentaram tendência de aumento na temperatura mínima do ar pelo teste de MannKendall nos anos de 1971 a 2006. No período de 1981 a 2016 o teste de Pettitt indicou os meses de março e junho com modificações na temperatura mínima do ar, este resultado também coincidiu com os meses com tendências positivas.

Palavras-chave: clima da Amazônia; Teste de Mann-Kendall; Teste de Pettitt; Aumento na temperatura mínima

\footnotetext{
MSc Candidate of the Postgraduate Program in Environmental Engineering Sciences, Center for Water Resources and Environmental Studies, University of São Paulo, São Carlos, SP, Brazil - camila.ruezzene@gmail.com

" PhD in Environmental Physics, Department of Environmental and Sanitary Engineering, Federal University of Rondônia, Ji-Paraná, RO, Brazil rgaguiar@gmail.com

II'PhD in Agricultural Meteorology, Departament of Meteorology, Federal University of Pelotas, Pelotas, RS, Brazil - graciela_fischer@yahoo.com.br Iv PhD in Environmental Physics, Department of Environmental and Sanitary Engineering, Federal University of Rondônia, Ji-Paraná, RO, Brazil naraluisar@gmail.com

$\checkmark$ PhD in Environmental Engineering Sciences, Postgraduate Program in Environmental Engineering Sciences Professor of University of São Paulo, Center for Water Resources and Environmental Studies, University of São Paulo, São Carlos, SP, Brazil - rbm1706@gmail.com

V' PhD in Energy Systems Planning, Postgraduate Program in Environmental Engineering Sciences Professor of University of São Paulo, Center for Water Resources and Environmental Studies, University of São Paulo, São Carlos, SP, Brazil - mauadffm@sc.usp.br
} 


\section{Introduction}

The climate of a given region is the result of interactions between various factors and geographical scales. Initially, the general circulation of the atmosphere as a climatic determinant, as well as the fronts, air masses and other systems responsible for weather and climate are highlighted. Therefore, at local and regional scales, questions related to latitude, altitude, continentality/sea level, topography of the terrain and land use and occupation are major conditioning factors in the intensification or attenuation of climatic elements.

The Amazon region has the largest tropical rainforest in the world and plays a major role in regulating global climate, acting as one of the largest water vapor storage centers in the tropical region, continuously "feeding" the general circulation of the atmosphere as and the results of the extensive forest (SUMILA, 2016, NOBRE et al., 2016, BOERS et al., 2017).

In recent years, studies focused on the Amazonian climate have been the focus of major research, mainly to identify possible trends and climatic changes in certain regions, which directly influence human activities, agriculture, energy system and population health (NOBRE et al. 2016; MARENGO; ESPINOZA, 2015; CAVIGLIA-HARRIS, 2018). The Mann-Kendall test and Pettitt method have been widely used in the identification of temperature trends in time series at local, regional and global scale in climate data analysis, and this may be referred to as an increase or decrease in the values of the variable in question (SALVIANO; GROPPO; PELLEGRINO, 2016; HAMED, 2009).

According to Silva et al. (2015) the Mann-Kendall method has the advantage of being a non-parametric test, that is, the data do not need to belong to a particular distribution, as well as the method being more robust against outliers because its calculation is based on the signal of the differences, not directly on the values of the variable and, finally, there is little sensitivity to abrupt breaks of time series.

In the second half of the 20th century, Rusticucci (2012) observed positive trends in minimum temperature and negative trends in South America in the presence of extreme cold events and a positive evolution of temperature in South America in the last decades. This marked increase in minimum temperature trends has been observed since 1960, followed also by an increase in maximum temperatures (SOARES et al., 2017; MARENGO; CAMARGO, 2008). In the southern region of Brazil has presented positive trends of minimum, medium and maximum temperature at annual and seasonal level (SANSIGOLO; KAYANO, 2010). And in the northern region there is a slight positive trend of the minimum temperature (TEJAS et al., 2012).

The use of methods that evaluate climatic trends is of paramount importance for understanding the microclimate of the region, especially if they try to understand the variability of the minimum air temperature by using time series, as well as possible increase or decrease of temperature, since such results allow the estimation of possible damages in socioeconomic activities, thus helping intersectoral decision making.

Thus, the study of minimum air temperature trend in Porto Velho is of great importance to elucidate questions related to the climate behavior of this region, and the present study had as objective to analyze the trends and the years of abrupt temperature changes that occurred in the Southwest Amazon in the years from 1971 to 2016 in the municipality of Porto Velho-RO.

\section{Material and Methods}

The study area is located in the municipality of Porto Velho, from the use of the Porto Velho Surface Weather Station (SBPV), under coordinates $08^{\circ} 42^{\prime} \mathrm{S}$ and $063^{\circ} 54^{\prime} \mathrm{W}$,

Figure 1 - Location of the Porto Velho Surface Weather Station.

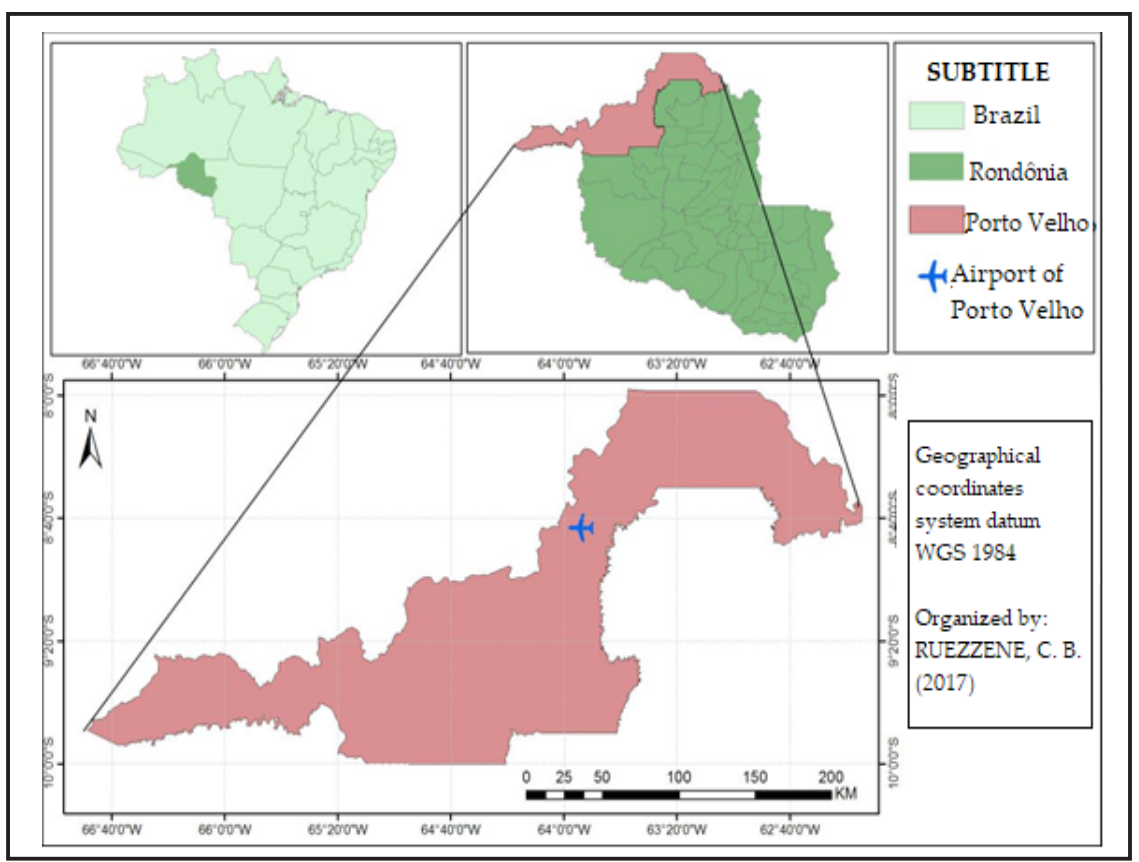


at an altitude of $88 \mathrm{~m}$. The choice of place of study was due to the availability of data, and in order to achieve a climatic trend, there is a need for a historical series of at least 30 years and also because it is a region that has suffered from strong influences on changes in use and occupation.

Porto Velho is located southwest of the North, encompasses the Western Amazon near the border of Brazil and Bolivia. According to IBGE (2016), the estimated population of Porto Velho is 511,219 inhabitants with a territorial unit area of $34,090,962 \mathrm{~km}^{2}$.

The climate in this region is tropical humid and warm, with insignificant annual thermal amplitude and remarkable daytime thermal amplitude, especially in winter (RONDÔNIA, 2010). Tejas et al. (2012) found in their studies an annual rainfall average for the years 1999 to 2010 of $2,160.8 \mathrm{~mm}$ and an average annual air temperature from 1983 to 2011 of $26.9^{\circ} \mathrm{C}$.

The predominant vegetation of the municipality is Open Ombrophylous Forest. The relief and floristic composition reveal four characteristic physiognomies of the region and one of them is represented in the study area, Open Lowland Ombrophylous Forest, with a flat to gently undulating relief, not exceeding $100 \mathrm{~m}$ altitude (SILVA; VINHA, 2002).

The measurement instrument used in this work was the thermohygrometer, which is the temperature sensor. The data was obtained from the surface meteorological station of the International Airport of Porto Velho, Governador Jorge Teixeira, and these are organized by the Sub-Division of Climatology and Meteorological Archives (PBCA), Sub-directorate of Research (SDP) of the Air Space Control Institute (ICEA), with 24 hours of operation.

In order to observe the possible minimum air temperature climate trends within the proposed climate understanding period, with at least 30 years of observations, the data were divided between 1971 and 2006 and from 1981 to 2016 to observe whether after ten years there was an increase or decrease of the minimum air temperature.
Thus, the data were submitted to the non-parametric Mann-Kendall (MK) test proposed by Mann (1945) and reformulated by Kendall (1975). This is a robust method that analyzes temporal trends, shows whether they are positive or negative, and whether their changes are statistically significant. It was adopted $\alpha=0.05$, where $\mathrm{H} 0$ : there is no trend in the series and H1: there is a trend in the series. However, due to the climatic data indicating autocorrelation, the Mann-Kendall test was chosen seasonally, being a variation of the traditional test where it incorporates the effect of autocorrelation in the statistical analyzes (LUIZ; CARDOSO; RIBEIRO, 2012).

Another non-parametric test also used in this work was the point of change of Pettitt (OGUNGBENRO; MORAKINYO, 2014). This test finds where there has been a sudden change in the mean in the time series, identifying for example the year of occurrence.

\section{Results and Discussion}

The region under study is composed of characteristic periods, with lower minimum temperatures in the months of July and August and higher in the months of December, February and March. Tables 1 and 2 describe the descriptive analyzes of the monthly minimum temperature of the years 1971 to 2006 and 1981 to 2016, respectively.

Tables 1 and 2 show the months of July and August with the lowest temperatures and in those same months with the highest standard deviations, showing a greater dispersion in the data set in these respective periods.

It is observed in Figure 2 the climatic variation of the minimum monthly temperature from 1971 to 2016 of the Municipality of Porto Velho-RO. The month with the lowest minimum temperature corresponded to July with $16.6^{\circ} \mathrm{C}$. Lower temperatures found mainly in this month may be associated with the phenomenon of cold, which reduces the minimum temperatures abruptly. And the month with the highest temperature was March with $21.9^{\circ} \mathrm{C}$.

Table 1 - Descriptive analysis of the minimum temperature from January to February from 1971 to 2006

\begin{tabular}{lcccc}
\hline Variable & Minimum & Maximum & Mean & Standard deviation \\
\hline Jan & 20.00 & 23.20 & 21.64 & 0.90 \\
Feb & 20.00 & 23.60 & 21.77 & 0.80 \\
Mar & 20.00 & 23.60 & 21.71 & 0.82 \\
Apr & 17.50 & 23.00 & 20.99 & 1.61 \\
May & 13.00 & 23.00 & 19.46 & 2.26 \\
Jun & 12.40 & 21.40 & 17.89 & 2.31 \\
Jul & 10.00 & 21.40 & 16.30 & 2.50 \\
Aug & 11.00 & 22.00 & 17.40 & 2.44 \\
Sep & 14.50 & 23.00 & 18.88 & 2.07 \\
Out & 17.40 & 23.00 & 20.98 & 1.18 \\
Nov & 14.00 & 22.60 & 20.65 & 1.83 \\
Dec & 19.30 & 23.90 & 21.67 & 0.90 \\
\hline
\end{tabular}


Table 2 - Descriptive analysis of the minimum temperature from January to February 1981 to 2016

\begin{tabular}{lcccc}
\hline Variable & Minimum & Maximum & Mean & Standard deviation \\
\hline Jan & 20.00 & 23.40 & 21.90 & 0.82 \\
Feb & 20.60 & 23.60 & 21.92 & 0.75 \\
Mar & 20.00 & 23.60 & 22.06 & 0.76 \\
Apr & 17.50 & 23.60 & 21.44 & 1.51 \\
May & 13.40 & 23.00 & 19.76 & 2.28 \\
Jun & 12.40 & 21.60 & 18.41 & 2.14 \\
Jul & 11.90 & 22.00 & 16.83 & 2.57 \\
Aug & 11.00 & 22.00 & 17.79 & 2.23 \\
Sep & 16.00 & 23.10 & 19.58 & 1.87 \\
Out & 17.40 & 25.40 & 21.50 & 1.45 \\
Nov & 14.00 & 23.70 & 20.95 & 1.93 \\
Dec & 20.40 & 23.90 & 21.97 & 0.80 \\
\hline
\end{tabular}

Figure 2 - Monthly variation of the minimum air temperature from 1971 to 2016.

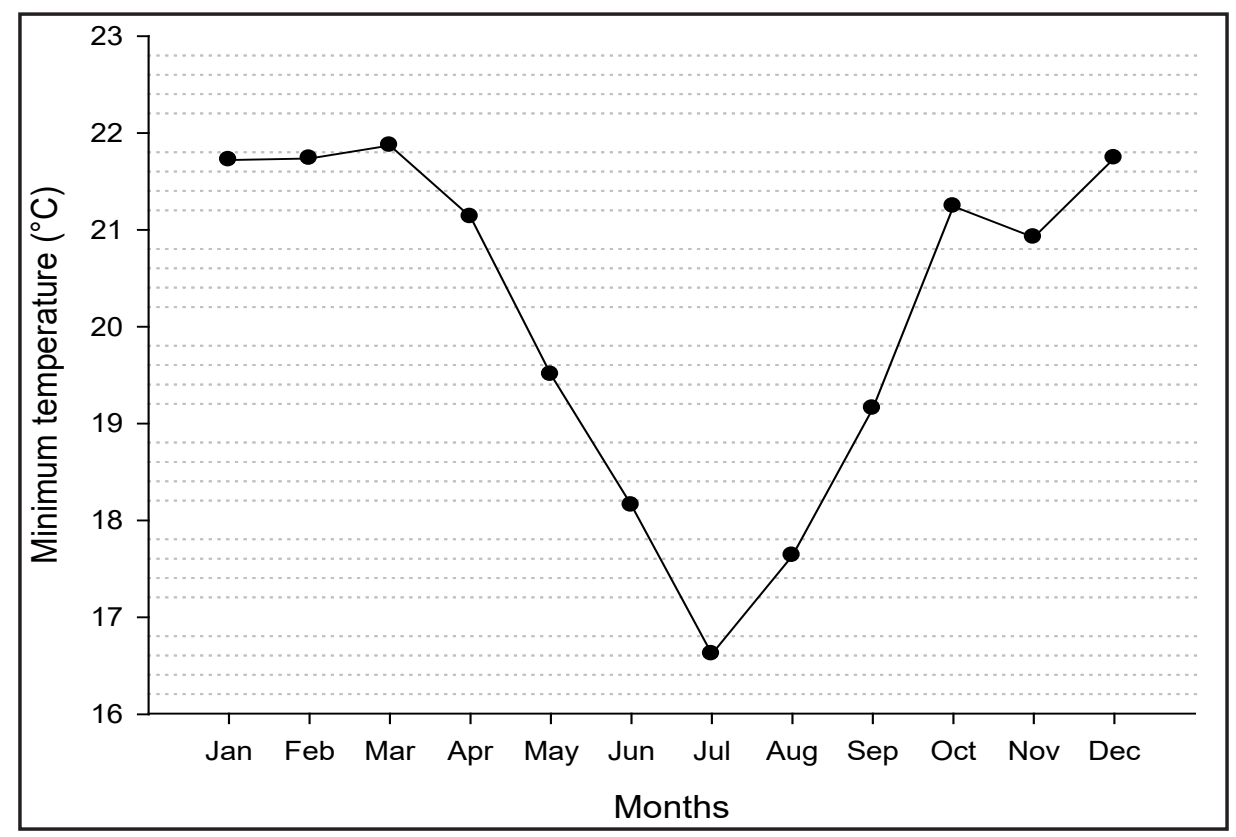

There was a positive and significant tendency of minimum air temperature for the months of January to April, June, September, October and December. Their respective angular coefficients, indicating how much increased each month, and the significant $\mathrm{p}$-value can be analyzed in table 3. The month of April and September did not present statistical significance to generate the coefficient for the years 1971 to 2006, only the trend in those months was observed.Figures 3 and 4 show the monthly minimum air temperature trends corresponding to the series from 1971 to 2006 and from 1981 to 2016, respectively.

In the studies of minimum and maximum temperature performed by Ávila et al. (2016) in Minas Gerais from 1961 to 2009 using the Mann-Kendall test, the authors verified that in January and October, $86.7 \%$ of the municipalities showed a significant tendency to increase the minimum air temperature and in January, of the 26 municipalities under study, 21 showed rates of increase of $0.5^{\circ} \mathrm{C}$ per decade, the other four with rates of increase between 0.5 and $1.0^{\circ} \mathrm{C}$ and one with rates higher than $1.0^{\circ} \mathrm{C}$.

Silva et al. (2015) in their analysis of trend of minimum and maximum temperature in the state of Paraná with a climatological series of 35 years (1976 to 2010) detected that tendencies of increase of the minimum air temperature were more significant than those observed by the maximum temperature.

The results of the annual trend analysis for three locations in the state of Acre, also by the Mann-Kendall test, showed trends of increase in minimum and mean air temperatures for the years 1970 to 2010 (DELGADO et al., 2012). 
Table 3 - Trend analysis of the minimum air temperature $\left({ }^{\circ} \mathrm{C}\right)$ generated by the monthly seasonal Mann-Kendall test with p-value and coefficient, from 1971 to 2006 and from 1981 to 2016.

\begin{tabular}{lcccc}
\hline Months & $\begin{array}{c}p \text {-value } \\
\text { (1971 to 2006) }\end{array}$ & $\begin{array}{c}p \text {-value } \\
\text { (1981 to 2016) }\end{array}$ & $\begin{array}{c}\text { Angular coefficient (1971 } \\
\text { to 2006) }\end{array}$ & $\begin{array}{c}\text { Angular coefficient } \\
\text { (1981 to 2016) }\end{array}$ \\
\hline Jan & 0,001 & ${ }^{*} 0,067$ & 0,048 & 0,022 \\
Feb & $<0,001$ & ${ }^{*} 0,490$ & 0,047 & 0 \\
Mar & 0,007 & 0,003 & 0,021 & 0,022 \\
Apr & 0,044 & ${ }^{*} 0,649$ & 0,050 & 0 \\
May & ${ }^{*} 0,122$ & ${ }^{*} 0,512$ & 0,054 & 0,017 \\
Jun & 0,025 & 0,024 & 0,086 & 0,072 \\
Jul & ${ }^{*} 0,245$ & ${ }^{*} 0,054$ & 0,050 & 0,076 \\
Aug & ${ }^{*} 0,287$ & ${ }^{*} 0,111$ & 0,033 & 0,061 \\
sep & 0,033 & ${ }^{*} 0,133$ & 0,072 & 0,044 \\
Oct & 0,003 & ${ }^{*} 0,064$ & 0,053 & 0,040 \\
Nov & $* 0,824$ & ${ }^{*} 0,177$ & 0 & 0,015 \\
Dec & $<0,001$ & ${ }^{*} 0,05$ & 0,072 & 0,014 \\
\hline
\end{tabular}

Figure 3 (a,b,c,d) - Months that showed a positive trend in minimum air temperature in Porto Velho from 1971 to 2006.

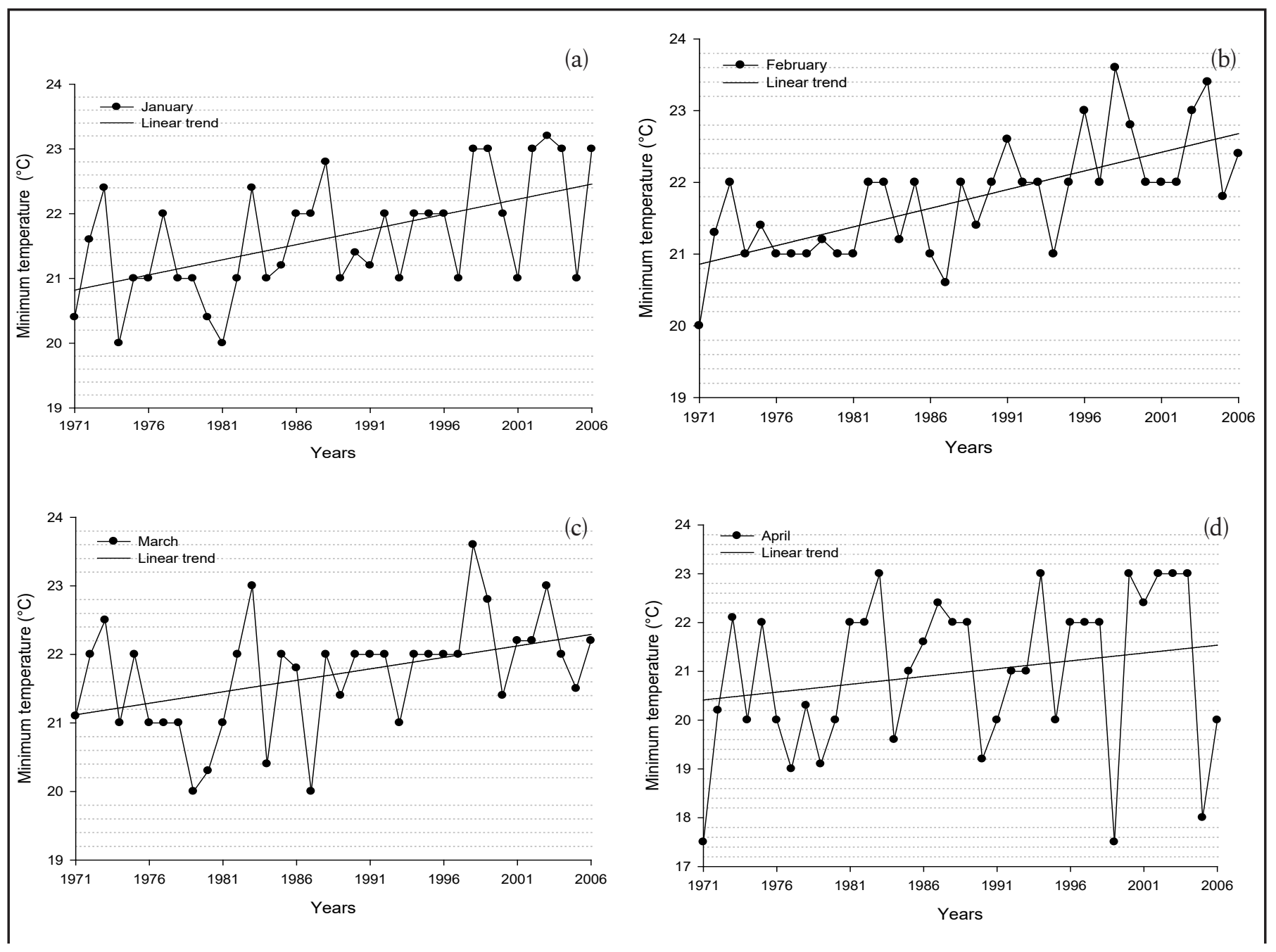

* (asterisks): corresponds to the months that were not significant. 
Figure 3 (e,f,g,h) - Months that showed a positive trend in minimum air temperature in Porto Velho from 1971 to 2006.
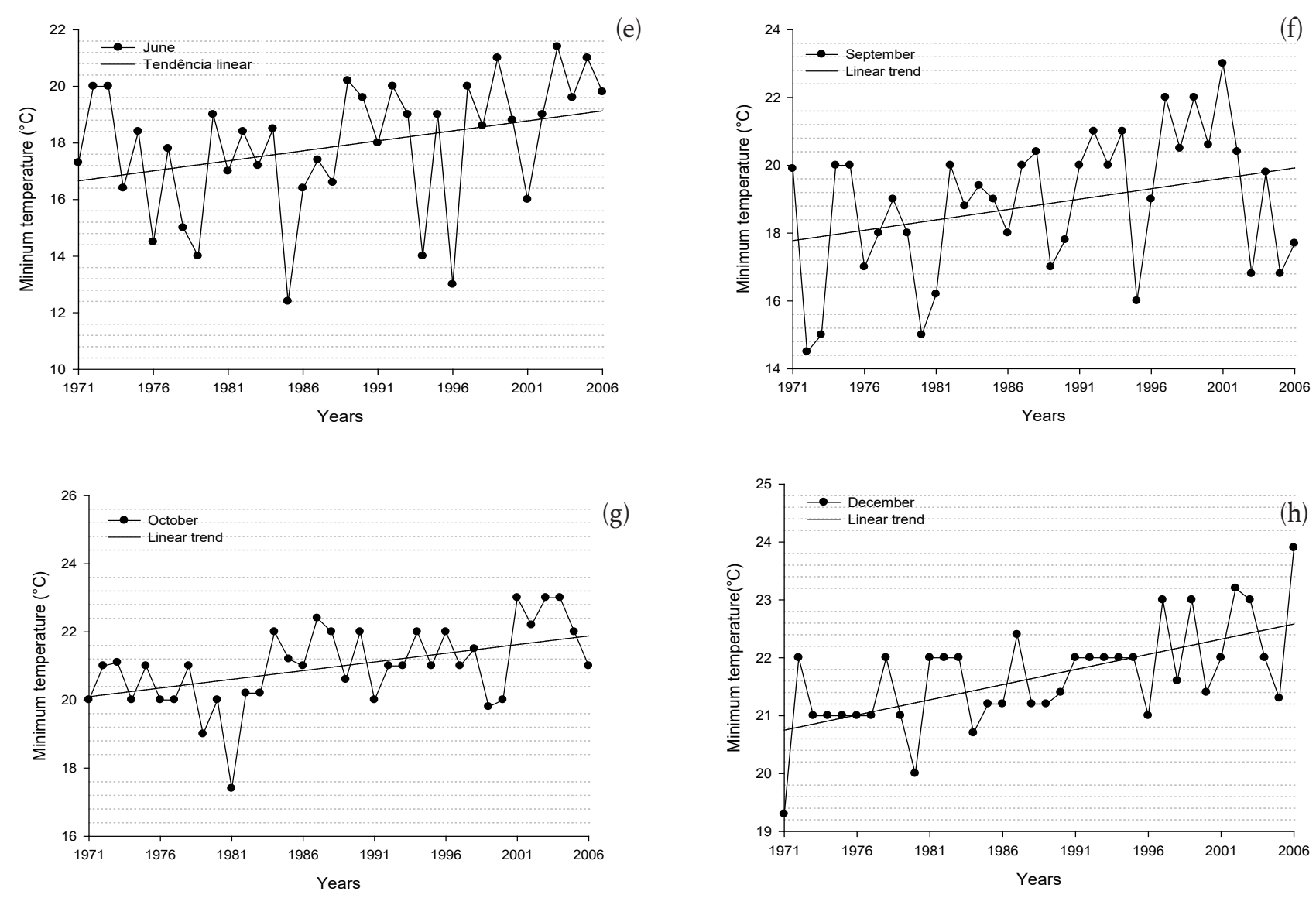

Figure 4 - Months that showed a significant positive trend in minimum air temperature in Porto Velho from 1981 to 2016.
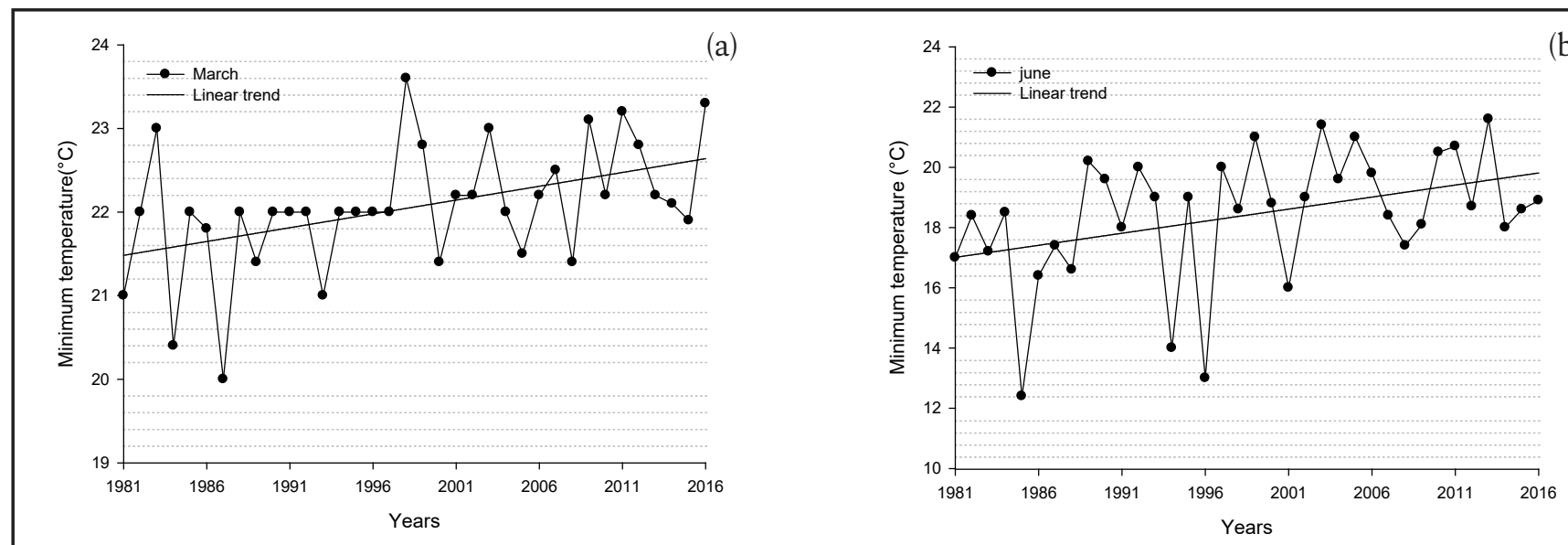

(b)

According to Delgado et al. (2012), the elevation of the minimum air temperature in the Cruzeiro do Sul and Rio Branco meteorological stations from 1970 to 2010 demonstrates the occurrence of warmer nights, which may be associated to the increase in ocean moisture transport towards the continent, as well as also to the urbanization of cities with the opening and paving of new streets and avenues and reduction of green areas, which may contribute to the modification of the local microclimate. Figures 5 and 6 show the Pettitt test from 1971 to 2006 and from 1981 to 2016.
The Pettitt test indicates abrupt change that occurs in a series of data. Thus, it is observed that the months of January, February, March, June, October and December presented abrupt changes of minimum air temperature for the years 1971 to 2006 , coinciding with most of the months in which there is a tendency to increase the minimum air temperature.

From 1981 to 2016 the Pettitt test indicated the months of March and June with changes in the minimum air temperature, this result also coincided with the months found with positive trends for the Mann-Kendall test. 
In the climatic series from 1971 to 2006 the month of January followed with the standard average of $21.1^{\circ} \mathrm{C}$ and there was an abrupt change in the year 1985 ( $\mathrm{p}$-value $=0.020$ ), passing then to an average of $22^{\circ} \mathrm{C}$, the month of February followed with an average of $21.2^{\circ} \mathrm{C}$ and the point of change occurred in the year 1987 ( $p$-value 0.000) obtaining an average of $22.2^{\circ} \mathrm{C}$. In the months of March and June, abrupt changes were observed in the years 1983 $(p$-value $=0.025)$ and $1988(p$-value $=0.041)$ respectively, with changes in the minimum air temperature from $21.4^{\circ} \mathrm{C}$ to $22.2^{\circ} \mathrm{C}$ and from $17^{\circ} \mathrm{C}$ to $18.8^{\circ} \mathrm{C}$ in the referred years.
Finally, we have the months of October and December that presented a change point in the years of 1983 ( $\mathrm{p}$-value $=0.004)$ and $1990(\mathrm{p}$-value $=0.004)$, respectively, with temperatures ranging from $20.1^{\circ} \mathrm{C}$ to $21.5^{\circ} \mathrm{C}$ and $21.2^{\circ} \mathrm{C}$ to $22.2^{\circ} \mathrm{C}$, in the same years mentioned above.

In the trend and climate-hydrological studies at the Ramsar Parna Pantanal site in Mato Grosso, Tozato, Dubreuil and Mello (2013) verified in Cuiabá and Cáceres an increase in minimum and maximum temperatures recorded by the Mann-Kendall test and the presence of rupture positive in the year of 1984 with an increase of

Figure 5 - Pettitt test with minimum air temperatures of Porto Velho from 1971 to 2006, averages before the point of change, with red dotted line, and mean after identification of the change (mu2), identified with green dotted.

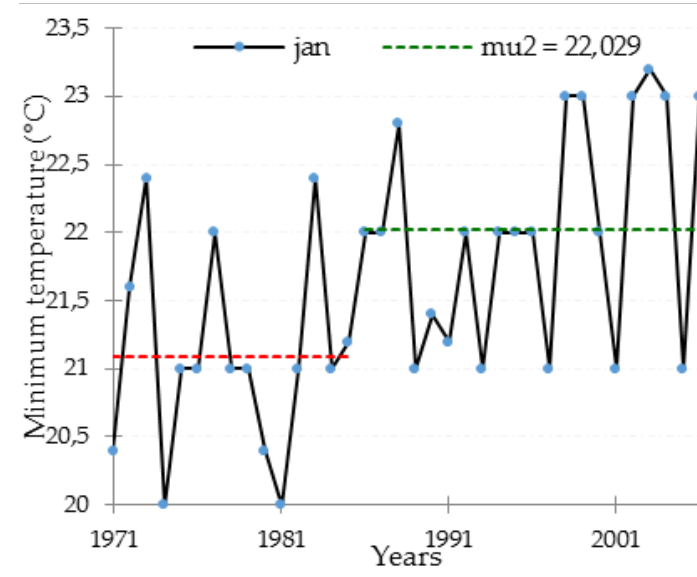

(a)

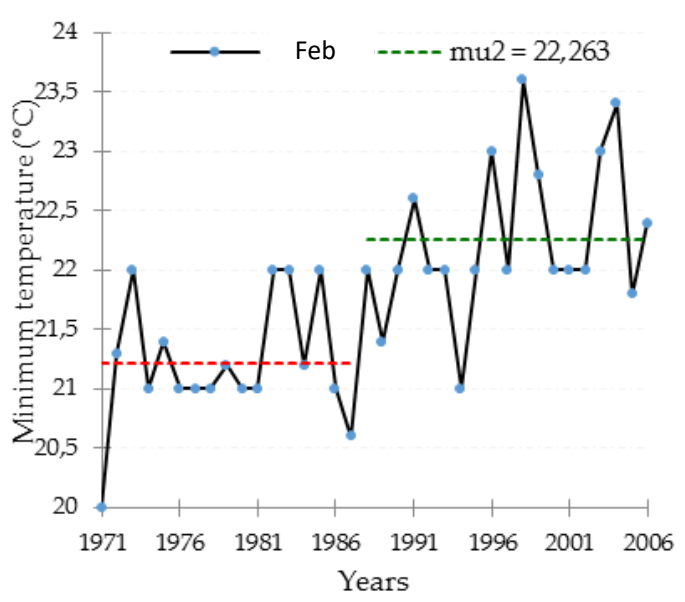

(b)

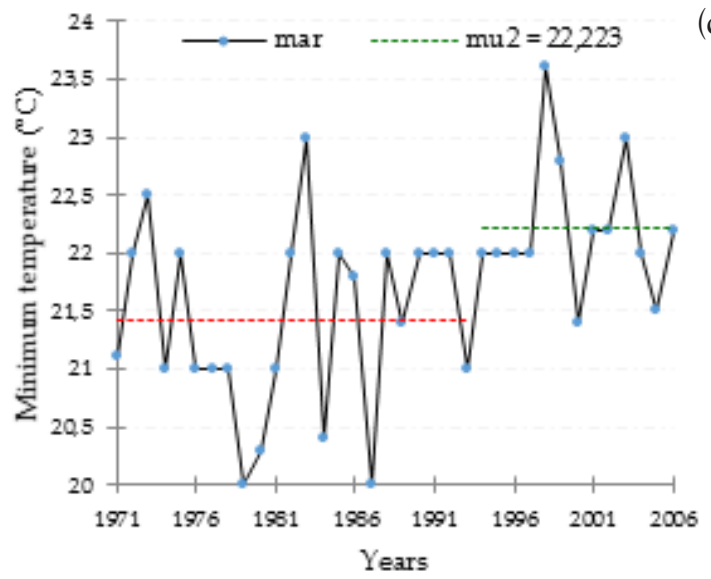

(c)
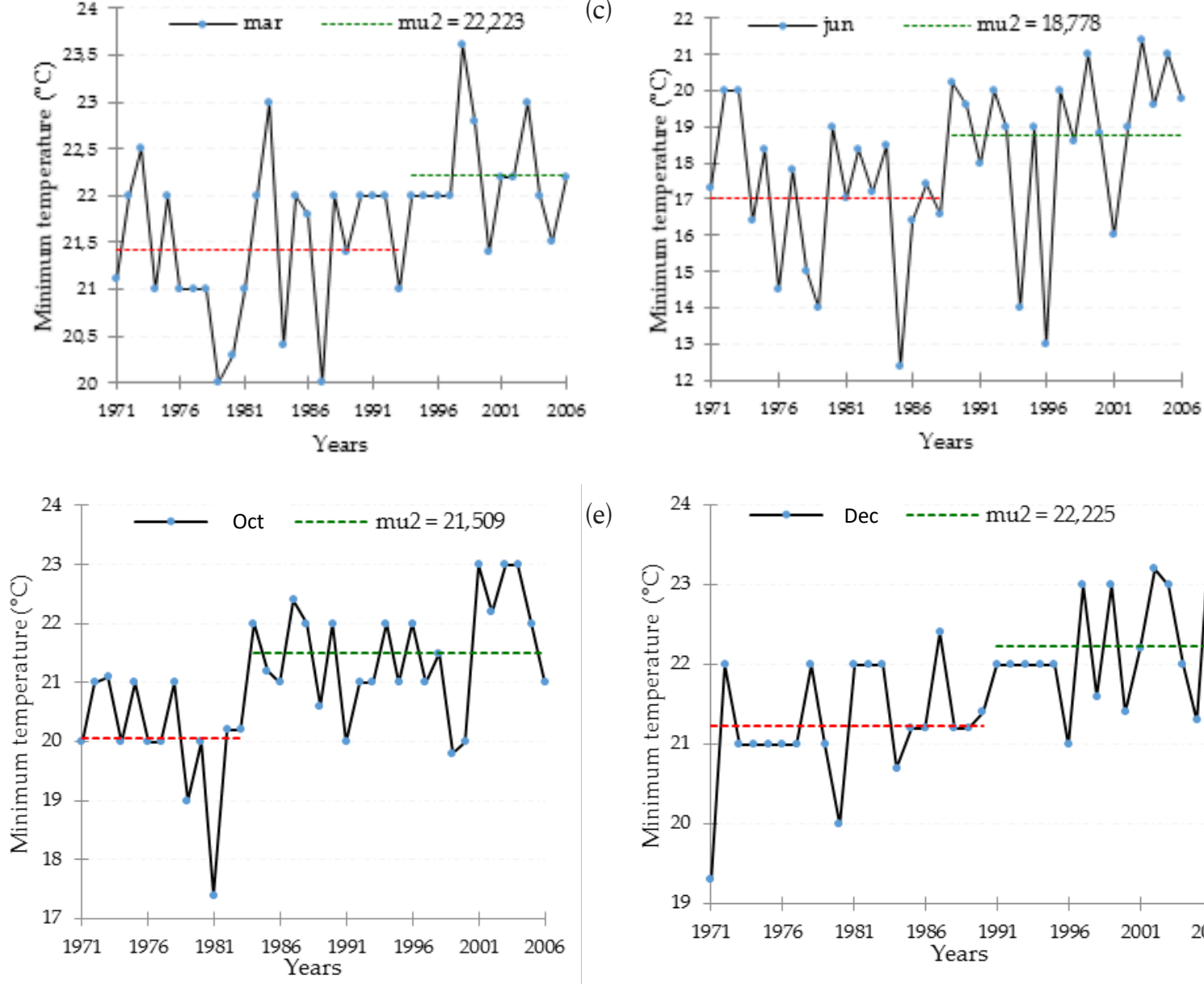

(e)

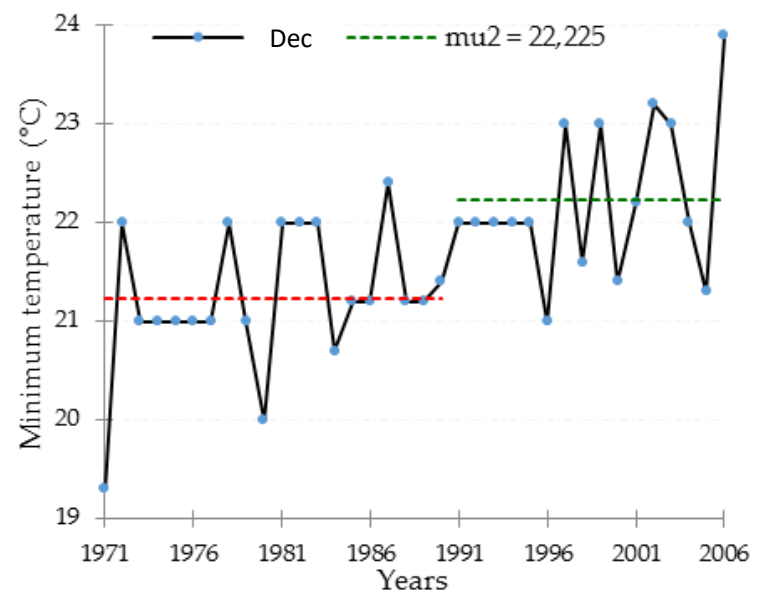


Figure 6 - Pettitt test with minimum air temperatures of Porto Velho from 1981 to 2016, averages before the point of change, with red dotted line, and mean after identification of the change (mu2), identified with green dotted.

(b)

(a)

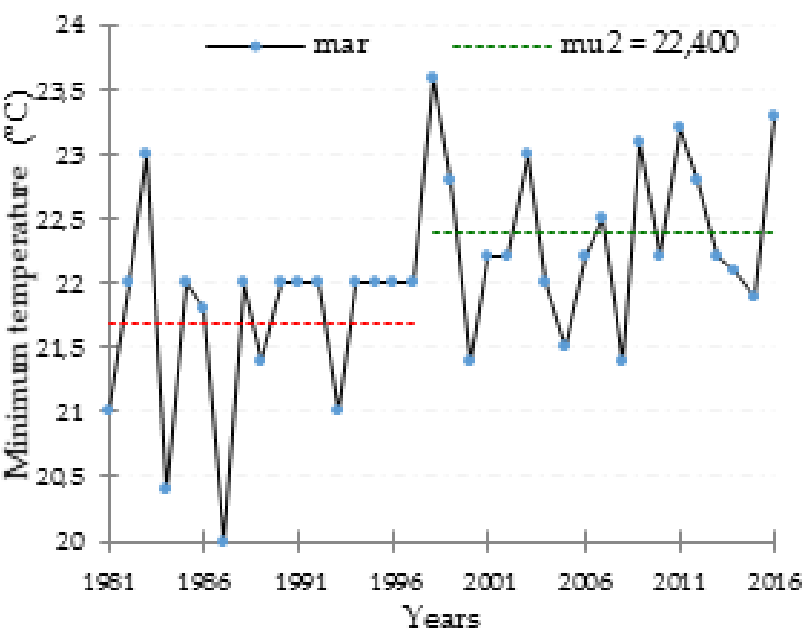

$0.7^{\circ} \mathrm{C}$ and $0.4^{\circ} \mathrm{C}$ for Cuiabá and sudden change in 1995 with an increase of $0.5^{\circ} \mathrm{C}$.

For the years 1981 to 2016, only the months of March in $1997(\mathrm{p}$-value $=0.009)$ and July in the year of $1996(\mathrm{p}$-value $=0.047$ ) were identified with a point of change in the minimum air temperature obtaining changes in temperature $21.7^{\circ} \mathrm{C}$ to $22.4^{\circ} \mathrm{C}$ and $15.5^{\circ} \mathrm{C}$ to $17.9^{\circ} \mathrm{C}$, respectively.

There were positive trends of minimum air temperature in 7 of the 11 measurement stations installed along the Tocantins River and its tributaries between the years of 1961 to 2013 and it was possible to identify changes in temperature in the late 1980s until the beginning of 2000 (PENEREIRO; MARTINS; BERETTA, 2016).

According to these authors, a possible explanation for the behavior of temperature tendencies may be related to the geographic characteristics of the region, with most occurrences of trends prevailing in regions of the cerrado biome.

Lima et al. (2013) in their studies of precipitation and temperature trends in the region of Portugal divided the data into three periods, from 1941 to 2006, from 1945 to 1975 and 1975 to 2006. Their results showed dominant heating trends, reflected in an increase in minimum air temperature in the period from 1941 to 2006 and detected a sudden change in temperature in the 1970.

In the years 1945 to 1975 were found negative trends of the indices of high temperatures and positive tendency for low temperatures and finally in the period of 1976 to 2006 resulted in a reversion in this pattern, which resulted in a negative tendency in the indices of high temperature and tendency negative in the coldest indices. There was a cooling trend until the mid-1970s, and after that period, a warming trend followed (LIMA et al., 2013).

Brulebois et al. (2015) analyzed by means of the Man$\mathrm{n}$-Kendall and Pettit test the minimum and maximum temperature of 119 meteorological stations located in France from 1961 to 2013, observed the point of change in the minimum and maximum temperature in 1987/1988,

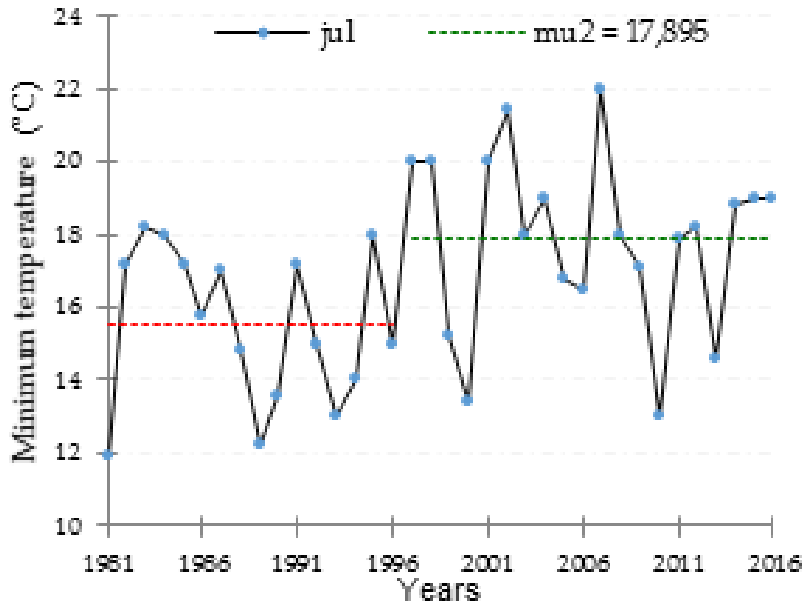

demonstrating that this change is present in all French metropolitan territory and therefore within that period of the last 50 years, this region had two different levels of temperature, one before the point of change and another after. Compared to these two periods, an increase of $0.92^{\circ} \mathrm{C}$ for the minimum air temperature and $1.1^{\circ} \mathrm{C}$ for the maximum temperature was found.

According to the aforementioned authors, this displacement of air temperature in the years 1987/88 may be the result of the combination of several factors, such as: increase in greenhouse gas concentration, leading to a progressive increase in radiative forcing; the reduction of aerosol emissions in the 1980s in Europe, leading to greater atmospheric transparency, thus allowing more solar radiation to reach the surface; the phase change of the negative North Atlantic Oscillations during the years prior to 1988 , for the persistence of positive phase conditions between 1988 and 1994; the persistence of the positive phase of the Atlantic Multi-Decadal Oscillation since 1995.

In trend analysis it is important to note that, in addition to global climate change, factors such as urbanization, heat islands, changes in use and occupation, and especially the effects of global phenomena of interdecadal oscillations, play a significant role in the temperature of cities.

The non-parametric trend tests used in the present study enabled a more comprehensive analysis of the behavior of the minimum air temperature climatic series, providing subsidies for more conclusions about the anomalies presented at some periods of the year.

\section{Conclusion}

A positive trend was observed for the months of January, February, March, April, June, September, October and December of 1971 to 2006 and for the years 1981 to 2016 only the months of March and June showed a trend of increasing the minimum air temperature. 
The Pettitt test indicated a sudden change in the data series coinciding with most of the months in which tendencies of increase of the minimum air temperature of the air were observed for the years of 1971 to 2006. In the period of 1981 to 2016 the test of Pettitt indicated the months of March and July with modifications in the minimum air temperature, this result also coincided with the same months found with positive tendencies for the Mann-Kendall test.

\section{Acknowledgments}

We thank the Coordination of Improvement of Higher Education Personnel (CAPES) and the National Council for Scientific and Technological Development (CNPq).

\section{References}

ALENCAR, L. P.; SEDIYAMA, G. C.; MANTOVANI, E. C.; MARTINEZ, M. A. Tendências recentes nos elementos do clima e suas implicações na evapotranspiração da cultura do milho em Viçosa - MG. Revista Engenharia Agrícola, v.31, n.4, p.631-642, 2011.

ÁVILA, F. L.; MELLO, R. C.; YANAGI, M. N. S.; NETO, S. B. O. Tendências de temperaturas mínimas e máximas do ar no Estado de Minas Gerais. Pesquisa Agropecuária Brasileira, v. 49, n. 4, p. 247256, 2014.

BOERS, Niklas et al. A deforestation-induced tipping point for the South American monsoon system. Scientific Reports, v. 7, n. 1, p.1-9, 2017.

BRULEBOIS, E.; CASTEL, T.; RICHARD, Y. SMITH, C. Hydrological response to an abrupt shift in surface air temperature over France in 1987/88. Journal of Hydrology, v. 531, n. 3, p. 892-901, 2015.

CAVIGLIA-HARRIS, J. L. Agricultural innovation and climate change policy in the Brazilian Amazon: Intensification practices and the derived demand for pasture. Journal Of Environmental Economics And Management, v. 90, p.232-248, 2018.

DELGADO, R. C.; SOUZA, L. P.; RODRIGUES, R. da A.; OLIVEIRA, E. C.; SANTOS, R. S. Tendência climática de aumento da temperatura mínima e da pressão de saturaçào do vapor d'água na Amazônia Ocidental. Enciclopédia Biosfera, v. 8, n. 15, p. 2584-2588, 2012.

HAMED, K. H. Exact distribution of the Mann-Kendall trend test statistic for persistent data. Journal of Hydrology, v. 365, n. 1-2, p.86-94, 2009.

INSTITUTO BRASILEIRO DE GEOGRAFIA E ESTATÍSTICA-IBGE. Censo 2016. Disponível em: http:// cidades,ibge,gov,br/xtras/perfil,php?codmun=110020. Acesso em 10 de ago. 2017.
KENDALL, M. G. Rank Correlation Methods, Charles Griffin, London, 1975.

LIMA, M. I. P.; SANTO, F. S.; RAMOS, A. M.; LIMA, J. L. M. P. Recent changes in daily precipitation and surface air temperature extremes in mainland Portugal, in the period 1941-2007. Atmospheric Research, v. 127, n. 10, p. 195-209, 2013.

LIMA, M. I. P.; SANTO, F. S.; RAMOS, A. M.; LIMA, J. L. M. P. Recent changes in daily precipitation and surface air temperature extremes in mainland Portugal, in the period 1941-2007. Atmospheric Research, v. 127, n. 10, p. 195-209, 2013.

LUIZ, G. C.; CARDOSO, H. C.; RIBEIRO, L. L. Aplicação do teste sazonal de Mann Kendall na análise de tendência da temperatura e umidade relativa do ar - Goiânia - GO: série histórica 1961 a 2008. Revista Geonorte, v.1, n.5, p.414 - 427, 2012.

MANN, H. B. Nonparametric tests against trend. Econometrica, v. 13, n. 3, p. 245-259, 1945.

MARENGO, J. A.; CAMARGO, C. C. Surface air temperature trends in Southern Brazil for 19602002. International Journal of Climatology, v. 28, n. 7, p.893-904, 2008.

MARENGO, J. A.; ESPINOZA, J. C. Extreme seasonal droughts and floods in Amazonia: causes, trends and impacts. International Journal Of Climatology, v. 36, n. 3, p.1033-1050, 2015.

NOBRE, Carlos A. et al. Land-use and climate change risks in the Amazon and the need of a novel sustainable development paradigm. Proceedings of The National Academy Of Sciences, v. 113, n. 39, p.10759-10768, 2016.

OGUNGBENRO, S. B.; MORAKINYO, T. E. Rainfall distribution and change detection across climatic zones in Nigeria. Weather and Climate Extremes, v. 5, n. 6, p. 1-6, 2014.

PENEREIRO, J. C.; MARTINS, L. S.; BERETTA, V. Z. Identificação de variabilidades e tendências interanuais em medidas hidro-climáticas na região hidrográfica do Tocantins-Araguaia, Brasil. Revista Brasileira de Climatologia, v. 18, n. 12, p. 219-241, 2016.

RONDÔNIA. Secretaria de Estado do Desenvolvimento Ambiental (SEDAM). Boletim Climatológico de Rondônia - 2008. Porto Velho: SEDAM, 2010.

RUSTICUCCI, M. Observed and simulated variability of extreme temperature events over South America. Atmospheric Research, v. 106, p.1-17, 2012. 
SALVIANO, M. F.; GROPPO, J. D.; PELLEGRINO, G. Q. Análise de Tendências em Dados de Precipitação e Temperatura no Brasil. Revista Brasileira de Meteorologia, v. 31, n. 1, p.64-73, 2016.

SANSIGOLO, C. A.; KAYANO, M. T. Trends of seasonal maximum and minimum temperatures and precipitation in Southern Brazil for the 1913-2006 period. Theoretical and Applied Climatology, v. 101, n. 1-2, p.209-216, 2010.

SILVA, R. B.; VINHA, E. Vegetação: Biodiversidade de Espécies Florestais, In: Atlas Geoambiental de Rondônia, Porto Velho: Secretaria de Estado do Desenvolvimento Ambiental - SEDAM, 2002, Fernandes, L. C.; Guimarães, S, C, P, (org.).

SILVA, W. L.; DERECZYNSKI, C.; CHANG, M.; FREITAS, M.; MACHADO, B. J.; TRISTÃO, L.; RUGGERI, J. Tendências observadas em indicadores de extremos climáticos de temperatura e precipitação no Estado do Paraná, Revista Brasileira de Meteorologia, v. 30, n. 2, p. 181-194, 2015.

SOARES, D. de B. et al. Can significant trends be detected in surface air temperature and precipitation over South America in recent decades? International Journal of Climatology, v. 37, n. 3, p.1483-1493, 2017.

SUMILA, T. Fontes e Destinos de Vapor de Água na Amazônia e os efeitos do desmatamento. Viçosa: UFV, 2016. Tese de (Doutorado em Meteorologia Aplicada), Universidade Federal de Viçosa, 2016.

TEJAS, T. G.; SOUZA, S. M. R.; FRANCA, R. R.; NUNES, D. D. Estudo da variabilidade climática em Porto Velho/ROBrasil, no período de 1982 a 2011, Revista de Geografia, v. 29, n. 2, p. 63-82, 2012.

TOZATO, H. de C.; DUBREUIL, V.; MELLO, N. A. T. Tendências e rupturas climato-hidrológicas no sítio Ramsar Parna Pantanal (MT, Brasil). Revista Brasileira de Climatologia, v. 13, n. 9, p. 164-184, 2013. 